\title{
KONSEP MANAJEMEN STRATEGI
}

Disusun Guna Memenuhi Tugas

Pada Mata Kuliah: Manajemen Strategi Perbankan Syariah

Dosen Pengampu: Dr. Fatimah, SE., MM

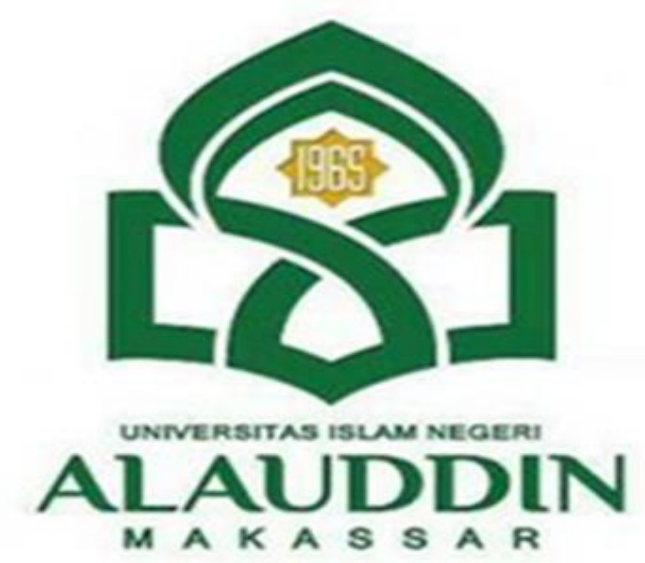

Disusun Oleh:

$\underline{\text { Kelompok } 1}$

Aisya Febrianti Masnur

$(90500118051)$

MuhWahyu Farayat Sulaiman

$(90500118061)$

UNIVERSITAS ISLAM NEGERI ALAUDDIN

FAKULTAS EKONOMI DAN BISNIS ISLAM

PROGRAM STUDI PERBANKAN SYARIAH 


\section{KATA PENGANTAR}

Puji dan syukur senantiasa penulis panjatkan kehadirat Allah SWT. Karena berkat Rahmat dan Hidayah-nyalah sehingga kami dapat menyelesaikan tugas makalah yang berjudul "KONSEP MANAJEMEN STRATEGI".

Tidak lupa kami mengucapkan salam kepada Nabi Muhammad SAW, selaku nabi yang dipilih oleh Allah untuk membawa umat manusia dari zaman kebodohan menuju zaman yang penuh dengan ilmu pengetahuan.

Makalah ini telah kami susun dengan maksimal dan mendaptkan referensi dari berbagai jurnal sehingga dapat memperlancar pembuatan makalah ini. Terlepas dari semua itu, kami menyadari bahwa masih ada kekurangan. Oleh karena itu, kami berharap semoga makalah ini dapat menambah pengetahuan dan pengalaman bagi para pembaca. Untuk kedepannya semoga pembaca dapat memperbaiki bentuk maupun menambah isi makalah agar menjadi lebih baik lagi.

Karena keterbatasan pengetahuan maupun pengalaman, kami yakin masih banyak kekurangan dalam makalah ini. Oleh karena itu, kami sangat mengharapkan saran dan kritik yang membangun dari pembaca demi kesempurnaan makalah ini.

Gowa, 12 September 2021

Penulis 


\section{DAFTAR ISI}

KATA PENGANTAR.

DAFTAR ISI

BAB I PENDAHULUAN
A. Latar Belakang
B. Rumusan Masalah
C. Tujuan Makalah
D. Manfaat Makalah.

BAB II PEMBAHASAN
A. Pengertian Manajemen Strategi
B. Proses Manajemen Strategi
C. Konsep Manajemen Strategi
D. Tipe-tipe ManajemenStrategi
E. Manfaat ManajemenStrategi
F. Manajemen Strategi Menurut Prespektif Islam

BAB III PENUTUP

A. Kesimpulan

DAFTAR PUSTAKA 


\section{BAB I PENDAHULUAN}

\section{A. Latar Belakang}

Dalam bidang ekonomi khususnya di lingkungan bisnis yang mengembangkan manajemen secara teoritis dan praktis, Manajemen Strategi telah cukup lama dikenal dan dikembangkan. Berbeda dengan di lingkungan organisasi non profit, khususnya bidang pendidikan, kehadiran Manajemen Strategi pada dasarnya merupakan suatu paradigma baru. Sebagai paradigma baru, jika diimplementasikan pada lingkungan organisasi pendidikan, tidak mungkin dilakukan sebagai kegiatan pengambil alihan seluruh kegiatannya sebagaimana dilaksanakan di lingkungan organisasi profit (bisnis), karena kedua organisasi tersebut satu dengan yang lain berbeda dalam banyak aspek, terutama dari segi filsafat yang mendasarinya dan tujuan yang hendak dicapai.

Pengimplementasian Manajemen Strategi di lingkungan organisasi bidang bisnis didasari oleh falsafah yang berisi nilai - nilai persaingan bebas antar organisasi bisnis sejenis, melalui pendayagunaan semua sumber yang dimiliki untuk mencapai tujuan yang bersifat strategi. Tujuan tersebut adalah mempertahankan dan mengembangkan eksistensi masing masing untuk jangka waktu panjang, melalui kemampuan meraih laba kompetitif secara berkelanjutan. Sedang organisasi pendidikan didasari oleh filsafat yang berisi nilai - nilai pengabdian dan kemanusiaan untuk mencerdaskan kehidupan bangsa. Perbedaan lain terletak pada pengorganisasian masing - masing. Setiap organisasi profit memiliki otonomi dalam menjalankan manajemennya, berupa kebebasan mewujudkan pengembangan organisasinya antara lain dengan memilih pengimplementasian Manejemen Strategik atau manajemen lainnya yang dinilai terbaik. Di organisasi non profit khususnya bidang pendidikan, organisasi ini diatur dengan manajemen umum oleh pemerintah Pusat ataupunn daerah, yang secara berencana dan sistematis telah menetapkan berbagai pengaturan yang mengikat dalam memilih dan mengimplementasikan manajemennya.

Pada makalah kali ini, kami akan membahas mengenai "Konsep Manajemen Strategi”. Kami mengambil materi dari beberapa sumber jurnal. Berikut isi dari makalah kami.

\section{B. Rumusan Masalah}

1. Apa pengertian manajemen strategi ?

2. Mengapa manajemen strategi dianggap penting?

3. Bagaimana proses manajemen strategi berlangsung? 
4. Apa saja konsep manajemen strategi?

5. Apa saja tipe-tipe manajemen strategi

6. Apa manfaat dan resiko manajemen strategi ?

\section{Tujuan Makalah}

1. Memahami tentang manajemen strategi

2. Mengetahui gambaran manajemen strategi

3. Untuk menambah wawasan atau pemahaman terhadap pentingnya manajemen straegi dalam perusahaan

\section{Manfaat Makalah}

1. Dapat menambah wawasan bagi pembaca

2. Menambah pengetahuan

3. Dapat menelaah pentingnya memahami sejarah manajemen strategi dan diterapkan dalam kehidupan 


\section{BAB II PEMBAHASAN}

\section{A. Pengertian Manajemen Strategi}

Kata strategi berasal dari bahasa Yunani strategos atau the art of general. Umumnya strategi berkembang dari domain militer. Bukubuku militer umumnya menggunakan kata strategi sebagai upaya untuk menaklukan musuh. Setiap peneliti, akademisi, maupun praktisi mempunyai padangan serta arti yang berbeda tentang strategi. Untuk memahami arti strategi, penulis mengemukakan beberapa arti strategi.

1. Strategi sebagai cara untuk mencapai tujuan organisasi. Beberapa pendapat yang sesuai dengan arti ini misalnya pendapat Thompson, Strickland, dan Gamble (2006) yang menyatakan bahwa strategi perusahaan terdiri dari gerakan pesaing, pendekatan bisnis yang digunakan manajer untuk meningkatkan pertumbuhan, usaha untuk menarik dan memuaskan pelanggan, dan mencapai target yang telah ditetapkan. Markides (2004) menyatakan bahwa proses untuk mengembangkan strategi superior adalah bagian dari perencanaan, bagian dari trial dan error, sampai perusahaan mendapatkan tujuannya. Mintzberg et al (1998) menyatakan bahwa strategi adalah usaha untuk mencapai tujuan organisasi melalui seperangkat perencanaan yang telah disusun secara formal oleh CEO.

2. Strategi didefinisikan sebagai competitive domain dalam organisasi. Secara umum, strategi organisasi didefinisikan oleh pola-pola strategi yang dilakukan oleh perusahaan. Minztberg et al (1998) menyatakan bahwa strategi sebagai pola berarti strategi adalah perilaku yang konsisten dan mudah diprediksi berdasarkan pola-pola yang telah dilakukan di masa lalu. Point yang ingin dikemukakan oleh Minztberg et al (1998) adalah setiap kali manajer atau CEO melakukan sebuah strategi yang 
relatif sama maka mereka dapat dikatakan melakukan strategi sebagai sebuah pola.

3. Strategi sebagai respon terhadap peluang dan ancaman eksternal, dan kekuatan dan kelemahan internal. Menurut pandangan ini strategi dipandang sebagai usaha internal perusahaan dalam memandang kekuatan eksternal. Design school Mintzberg et al (1998) merupakan bentuk konkrit dari pandangan ini. Penciptaan strategi dihasilkan dari interaksi internal dan eksternal perusahaan, dan implementasi strategi berasal dari proses penciptaan ini. Konsep Porter (1980) menyatakan bahwa kemampuan perusahaan menganalisis industri (eksternal) akan membantu perusahaan menganalisis pesaing. Dengan memahami industri, maka perusahaan mampu merespon persaingan dengan menggunakan strategi generik yang sesuai. Konsep rantai nilai yang dikemukakan Porter (1985) merupakan cara internal perusahaan untuk mengoptimalkan kemampuannya untuk menghadapi persaingan. Analisis lima tekanan, pemilihan strategi generik dan penggunaan konsep rantai nilai akan membantu perusahaan menghadapi persaingan. ${ }^{1}$

Manajemen Strategi merupakan rangkaian dua perkataan terdiri dari kata "Manajemen" dan "Strategi" yang masing - masing memiliki pengertian tersendiri, yang setelah dirangkaikan menjadi satu terminologi berubah dengan memiliki pengertian tersendiri pula. Menurut Hadari Nawawi (2005:148-149), pengertian manajemen strategi ada 4 (empat). Pengertian pertama Manajemen Strategi adalah "proses atau rangkaian kegiatan pengambilan keputusan yang bersifat mendasar dan menyeluruh, disertai penetapan cara melaksanakannya, yang dibuat oleh manajemen puncak dan dimplementasikan oleh

1 B. Elnath Aldi, "UPAYA GENERALISASI KONSEP MANAJEMEN STRATEGIK", JURNAL ILMU EKONOMI \& SOSIAL, VOL.VI, NO. 2, OKTOBER 2015, Universitas Katolik Indonesia Atma Jaya, hal.66-67. 
seluruh jajaran di dalam suatu organiasasi, untuk mencapai tujuannya". Dari pengertian tersebut terdapat beberapa aspek yang penting, antara lain: (a) Manajemen Strategi merupakan proses pengambilan keputusan. (b) Keputusan yang ditetapkan bersifat mendasar dan menyeluruh yang berarti berkenaan dengan aspek aspek yang penting dalam kehidupan sebuah organisasi, terutama tujuannya dan cara melaksanakan atau cara mencapainya. (c) Pembuatan keputusan tersebut harus dilakukan atau sekurang kurangnya melibatkan pimpinan puncak (kepala sekolah), sebagai penanggung jawab utama pada keberhasilan atau kegagalan organisasinya. (d) Pengimplementasian keputusan tersebut sebagai strategi organisasi untuk mencapai tujuan strategiknya dilakukan oleh seluruh jajaran organisasi (warga sekolah), seluruhnya harus mengetahui dan menjalankan peranan sesuai wewenang dan tanggung jawab masing - masing. (e) Keputusan yang ditetapkan manajemen puncak (kepala sekolah) harus diimplementasikan oleh seluruh warga sekolah dalam bentuk kegiatan/ pelaksanaan pekerjaan yang terarah pada tujuan strategi organisasi.

Pengertian manajemen strategi yang kedua adalah "usaha manajerial menumbuhkembangkan kekuatan organisasi untuk mengeksploitasi peluang yang muncul guna mencapai tujuannya yang telah ditetapkan sesuai dengan misi yang telah ditentukan”. Dari pengertian tersebut terdapat konsep yang secara relatif luas dari pengertian pertama yang menekankan bahwa "manajemen strategi merupakan usaha manajerial menumbuhkembangkan kekuatan organisasi”, yang mengharuskan kepala sekolah dengan atau tanpa bantuan manajer bawahannya (Wakasek, Pembina Osis, Kepala Tata Usaha), u ntuk mengenali aspek - aspek kekuatan organisasi yang sesuai dengan misinya yang harus ditumbuhkembangkan guna mencapai tujuan strategi yang telah ditetapkan. Untuk setiap peluang atau kesempatan yang terbuka harus dimanfaatkan secara optimal. 
Pengertian yang ketiga, Manajemen Strategi adalah "arus keputusan dan tindakan yang mengarah pada pengembangan strategi yang efektif untuk membantu mencapai tujuan organisasi”. Pengertian ini menekankan bahwa arus keputusan dari para pimpinan organisasi (Ka Dinas, Kepala Sekolah) dan tindakan berupa pelaksanaan keputusan, harus menghasilkan satu atau lebih strategis, sehingga dapat memilih yang paling efektif atau yang paling handal dalam usaha mencapai tujuan organisasi.

Pengertian yang keempat, "manajemen strategi adalah perencanaan berskala besar (disebut Perencanaan Strategi) yang berorientasi pada jangkauan masa depan yang jauh (disebut VISI), dan ditetapkan sebagai keputusan manajemen puncak (keputusan yang bersifat mendasar dan prinsipil), agar memungkinkan organisasi berinteraksi secara efektif (disebut MISI), dalam usaha menghasilkan sesuatu (Perencanaan Operasional) yang berkualitas, dengan diarahkan pada optimalisasi pencapaian tujuan (disebut Tujuan Strategik) dan berbagai sasaran (Tujuan Operasional) organisasi.” Pengertian yang cukup luas ini menunjukkan bahwa Manajemen Strategi merupakan suatu sistem yang sebagai satu kesatuan memiliki berbagai komponen yang saling berhubungan dan saling mempengaruhi, dan bergerak secara serentak ke arah yang sama pula. Komponen pertama adalah Perencanaan Strategi dengan unsur - unsurnya yang terdiri dari Visi, Misi, Tujuan Strategi organisasi. Sedang komponen kedua adalah Perencanaan Operasional dengan unsur - unsurnya adalah Sasaran atau Tujuan Operasional, Pelaksanaan Fungsi - fungsi manajemen berupa fungsi pengorganisasian, fungsi pelaksanaan dan fungsi 
penganggaran, kebijaksanaan situasional, jaringan kerja Internal dan eksternal, fungsi kontrol dan evaluasi serta umpan balik. ${ }^{2}$

Setelah membaca beberapa pengertian diatas dapat kami simpulkan manajemen strategi itu penting. Alasan pertama yang paling penting adalah bahwa hal itu dapat membedakan seberapa baik kinerja perusahaan. Organisasi yang menggunakan Manajemen Strategik mempunyai tingkat kinerja yang lebih tinggi dan itu membuatnya cukup penting bagi para manajer. Alasan kedua, hal tersebut penting berhubungan dengan fakta bahwa manaer di semua jenis dan ukuran organisasi terus menghadapi situasi yang berubah. Mereka menghadapi ketidakpastian dengan menggunakan proes manajemen strategik untuk mmeriksa faktor-faktor yang relevan dan memeutuskan tindakan apa yang kan diambil. Alasan terakhir, manajemen merupakan hal yang penting karena organisasi bersifat kompleks dan beragam. Setiap bagian harus bekerja untuk mencapai tujuan organisasi.

\section{B. Proses Manajemen Strategi}

1. Menetapkan arah dan misi organisasi Setiap organisasi pasti mempunyai visi,misi dan tujuan.

Visi, misi dan tujuan ini akan menentukan arah yang akan dituju oleh organisasi. Tanpa adanya visi,misi, dan tujuan maka kinerja organisasi akan berjalan acak dan kurang jelas serta mudah berubah dan diombangambingkan oleh situasi eksternal. Perubahan yang tidak mempunyai visi, misi dan tujuan seringkali bertindak spontantitas dan kurang sistematis seperti yang dilakukan oleh pedagang kecil hanya untuk memperoleh sesuap nasi. Tentunya hal ini tidak boleh terjadi

2 Sujadi, "KONSEP MANAJEMEN STRATEGIK SEBAGAI PARADIGMA BARU DI LINGKUNGAN ORGANISASI PENDIDIKAN", JURNAL STIE SEMARANG, VOL 3, NO 3, Edisi Oktober 2011, STIE Semarang, hal. 2-3. 
bagi suatu organisasi bisnis (perusahaan) apalagi jika perusahaan tersebut boleh dikatakan skala menengah dan atas.

2. Memahami lingkungan internal dan eksternal

Tujuan analisis lingkungan adalah untuk dapat mengerti dan memahami lingkungan oraganisasi sehingga manajemen akan dapat melakukan reaksi secara tepat terhadap setiap perubahan, selain itu agar manajemen mempunyai kemampuan merespon berbagai isu kritis mengenai lingkungan yang mempunyai pengaruh yang cukup kuat terhadap perusahaan. Lingkungan terdiri dari lingkungan eksternal dan lingkungan internal. Lingkungan eksternal berada di luar perusahaan sedangkan lingkungan internal berada di dalam perusahaan. Lingkungan eksternal: Memiliki dua variabel yakni peluang (opportunity) dan acaman (threats) Terdiri dari dua bagian yaitu lingkungan tugas dan lingkungan umum Lingkungan internal: Memiliki dua variabel yakni kekuatan (strength) dan kelemahan (weakness). Mencakup semua unsur bisnis yang ada di dalam perusahaan seperti struktur organisasi perusahaan, budaya perusahaan dan sumber daya.

3. Merumuskan strategi

Formulasi strategi melibatkan penetapan serangkaian tindakan yang tepat guna mencapai tujuan perusahaan. Formulasi strategi ini meliputi pengembangan misi bisnis, analisa SWOT: mengidentifikasi peluang dan ancaman eksternal serta mengukur dan menetapkan kelemahan dan kekuatan internal dan menetapkan tujuan jangka panjang.

Analisa SWOT

SWOT merupakan singkatan dari strength (kekuatan), weakness (kelemahan), opportunity (peluang) dan threats (ancaman). Pendekatan ini mencoba menyeimbangkan 
kekutaan dan kelemahan internal organisasi dengan peluang dan ancaman lingkungan eksternal organisasi.

a. Kekuatan (strength): merupakan suatu kondisi, perusahaan mampu melakukan semua tugasnya sangat baik (diatas rata-rata industri).

b. Kelemahan (weakness): merupakan suatu kondisi, perusahaan kurang mampu melaksanakan tugasnya secara baik di karenakan sarana dan prasarananya kurang mencukupi.

c. Peluang (opportunity): merupakan suatu potensi bisnis atau setiap peluang dan kesempatan menguntungkan yang dapat diraih oleh perusahaan yang masih belum di kuasai oleh pihak pesaing dan masih belum tersentuh oleh pihak manapun.

d. Ancaman (threats): merupakan suatu keadaan, perusahaan mengalami kesulitan yang disebabkan persaingan yang jika dibiarkan maka perusahaan akan mengalami kesulitan dikemudiaan hari.

4. Mengimplementasikan strategi Didalam implementasi strategi, perusahaan diharapkan menetapkan atau merumuskan tujuan perusahaan tahunan (annual objective of the business), memikirkan dan merumuskan kebijakan, memotivasi karyawan serta mengalokasikan sumber daya sehingga strategi yang telah di formulasikan dapat dilaksanakan. Mengimplementasikan berarti menggerakkan para karyawan dan manajer untuk menempatkan strategi yang telah formulasikan menjadi tindakan nyata. Implementasi strategi memerlukan kinerja dan disiplin yang tinggi tetapi juga diimbangi dengan imbalan yang memadai. Tantangan implementasi adalah mengajak para manajer dan karyawan melalui organisasi agar mau bekerja 
penuh kebanggaan dan antusias ke arah pencapaian tujuan yang telah ditetapkan.

5. Mengevaluasi dan mengawasi strategi

Evaluasi dan pengawasan strategi merupakan tahap terakhir di dalam proses strategi. Pada dasarnya evaluasi strategi mencakup 3 hal, yaitu:

1. Mereview faktor internal dan eksternal yang menjadi dasar bagi strategi yang sedang berlangsung,

2. Mengukur kinerja yang telah dilakukan,

3. Mengambil berbagai tindakan perbaikan. Evaluasi strategi sangat diperlukan sebab keberhasilan perusahaan dewasa ini tidak menjadi jaminan keberhasilan perusahaan di masa yang akan datang. ${ }^{3}$

\section{Konsep Manajemen Strategi}

Manajemen strategis didasarkan pada pemahaman organisasi yang jelas tentang misinya; visinya untuk di mana ia ingin berada di masa depan; dan nilai-nilai yang akan memandu tindakannya. Proses ini membutuhkan komitmen untuk perencanaan strategis, bagian dari manajemen bisnis yang melibatkan kemampuan organisasi untuk menetapkan tujuan jangka pendek dan jangka panjang.

Perencanaan strategis juga mencakup perencanaan keputusan strategis, kegiatan, dan alokasi sumber daya yang diperlukan untuk mencapai tujuan tersebut. Memiliki proses yang ditetapkan untuk mengelola strategi akan membantu organisasi membuat keputusan logis dan mengembangkan tujuan baru dengan cepat untuk mengimbangi perkembangan teknologi, pasar, dan kondisi bisnis. Manajemen strategis dapat, dengan demikian, membantu organisasi

\footnotetext{
${ }^{3}$ Onny Juwono, "ANALISIS MANAJEMEN STRATEGIK PERUSAHAAN WARALABA (FRANCHISE) (STUDI KASUS DI RESTORAN CEPAT SAJI McDONALD'S) PERIODE OKTOBER - DESEMBER 2011", Jurnal Ekonomika dan Manajemen, hal. 9-11.
} 
memperoleh keunggulan kompetitif, meningkatkan pangsa pasar dan merencanakan masa depannya.

Ilmuwan manajemen Kanada Henry Mintzberg menyimpulkan bahwa proses manajemen strategis adalah hal dinamis. Dalam makalahnya tahun 1987, "The Strategy Concept I: Five Ps for Strategi," ia berpendapat "bidang manajemen strategis tidak mampu mengandalkan satu definisi strategi." Sebaliknya, ia menjabarkan lima definisi strategi dan keterkaitannya:

Plan (Rencana): Strategi sebagai tindakan yang secara sadar dimaksudkan untuk menghadapi suatu situasi.

Ploy (Taktik) : Strategi sebagai manuver untuk mengecoh pesaing, yang juga bisa menjadi bagian dari rencana.

Pattern (Pola): Strategi yang berasal dari konsistensi dalam perilaku, baik yang dimaksudkan atau tidak dan yang dapat terlepas dari suatu rencana.

Position (Posisi): Strategi sebagai kekuatan penengah atau kecocokan antara organisasi dan lingkungan, yang dapat kompatibel dengan salah satu atau semua P.

Perspektif: Strategi sebagai konsep atau cara yang sudah tertanam dalam memahami dunia - misalnya, penentu kecepatan yang agresif vs penggerak akhir - yang dapat kompatibel dengan salah satu atau semua P. ${ }^{4}$

\section{Tipe-tipe Manajemen Strategi}

Pada prinsipnya strategi di kelompokkan berdasarkan tiga tipe strategi yaitu, stategi manajemen, strategi investasi dan strategy bisnis.

○ Strategi manajemen Strategi manajemen meliputi strategi yang dapat di lakukan oleh manajemen dengan orientasi pengembangan strategi secara makro misalnya, strategi pembengangan produk, strategi penerapan harga, startegi

${ }^{4}$ http://asaraagama.com/manajemen/manajemen-strategis diakses pada pukul 23.0 tanggal 12 September 2021 
akuisisi, strategi.pengembangan pasar, strategi mengenai keuangan dan sebagainya.

- Strategi investasi Strategi ini merupakan kegiatan yang berorientasi pada investasi.Misalnya, apakah perusahaan ingin melakukan strategi pertumbuhan yang angresif atau berusaha mengadakan penetrasi pasar, strategi bertahan, strategi pembangunan kembali suatu divisi baru atau strategi divestasi dan sebagainya.

- Strategi bisnis Strategi bisnis ini sering juga di sebut strategi bisnis secara fungsional karena strategi ini berorientasi pada fungsi fungsi kegiatann manajemen, misalnya strategi pemasaran,strategi produksi atau operasional,startegi distribusi, strategi organisasi, dan strategi strategi yang berhubungan dengan keuangan. ${ }^{5}$

\section{E. Manfaat Manajemen Strategi}

Adapun manfaat manajemen strategis menurut David (2011) adalah sebagai berikut: "Manfaat utama dari manajemen strategis untuk membantu organisasi merumuskan strategi-str ategi yang lebih baik melalui penggunaan pendekatan terhadap pilihan strategi yang lebih sistematis, logis dan rasional, dan komunikasi adalah kunci bagi manajemen strategis yang berhasil." Manajemen strategis mampu memberikan berbagai keuntungan untuk perusahaan, baik keuntungan keuangan maupun yang bukan keuntungan keuangan. Pada sisi keuangan,manajemen strategis mengarahkan perusahaan dalam melakukan perbaikan dalam bagian penjualan, dan laba. Pada sisi non keuangan, manajemen strategis membantu perusahaan dalam meningkatkan produktivitas karyawan, menyadari ancaman dan peluang bagi perusahaan dan kekuatan serta kelemahan dalam perusahaan.

${ }^{5}$ Rangkuti, Fredy, "Strategi promosi yang kreatif dan Analisis Kasus Intergrated Marketing Communication, Jakarta: PT. Gramedia Pustaka Utama, 2009, hal. 6. 
Menurut (UNASO, 2003) : „Perencanaan strategis adalah proses penentuan: (1) apa yang hendak dicapai oleh organisasi Anda; (2) bagaimana Anda akan mengarahkan organisasi dan sumber daya untuk mencapai tujuan ini selama beberapa bulan dan tahun. "Pentingnya perencanaan strategis bagi pemerintah sangat menonjol karena disanalah terlihat dengan jelas peranan dari pemerintah dalam mengkoordinasikan semua unit kerja. Bryson (2007:5), meskipun terkesan bahwa perencanaan strategis disusun untuk memperoleh laba, namun perencanaan strategis juga dapat diterapkan pada beberapa jenis organisasi, yaitu sebagai berikut :

a. Lembaga publik, departemen, atau divisi penting dalam organisasi.

b. Pemerintahan umum, seperti pemerintahan city,county, atau negara bagian.

c. Organisasi nirlaba yang pada dasarnya memberikan pelayanan publik.

d. Fungsi khusus yang menjembatani batasan-batasan organisasi dan pemerintah, seperti transportasi, kesehatan atau pendidikan.

e. Seluruh komunitas, kawasan perkotaan atau metropolitan, daerah, atau negara bagian. Menurut Bryson, (2007 : 1213), perencanaan strategis merupakan satu bagian yang penting karena dapat membantu organisasi :

i. Berpikir secara strategis dan mengembangkan strategi - strategi yang efektif.

ii. Memperjelas arah masa depan.

iii. Menciptakan prioritas.

iv. Membuat keputusan sekarang dengan mengingat konsekuensi masa depan.

v. Mengembangkan landasan yang koheren dan kokoh bagi pembuatan keputusan. 
vi. Menggunakan keleluasaan yang maksimum dalam bidang - bidang yang berada di bawah kontrol organisasi.

vii. Membuat keputusan yang melintasi tingkat dan fungsi.

viii. Memecahkan masalah utama organisasi.

ix. Menangani keadaan yang berubah dengan cepat secara efektif.

x. Membangun kerja kelompok dan keahlian. ${ }^{6}$

\section{F. Manajemen Strategi Menurut Prespektif Islam}

Manajemen strategi adalah sebuah proses untuk menjalankan sebuah perusahaan dan yang akan mengatur semua aktifitas perusahaan yang dijalankan. Dengan manajemen ini perusahaan tersebut akan mengetahui arah, gerak, langkah, dan tujuan perusahaan. Didalam islam juga sudah diatur sedemikian rupa, dalam perspektif Islam manajemen diistilahkan dengan kata at-tadbir (pengaturan).

Sebagaimana dalam firman Allah SWT dalam surah As-Sajadah ayat 5. Artinya : "Dia mengatur urusan dari langit ke bumi, kemudian (urusan) itu naik kepada-Nya dalam suatu hari yang kadarnya adalah seribu tahun menurut perhitunganmu”. (As-Sajadah: 5). Dari ayat ini kita dapat mengambil 'ibroh, bahwasanya Allah sudah mengatur seluruh alam jagat raya ini, dan ini merupakan tanda-tanda kekuasaan dan kebesaran Allah SWT.

Dalam perspektif Islam tahapan manajemen ini ada 4, yaitu perencanaan (ahdaf), pelaksanaan (tatbiq), evaluasi (muhasabah), dan pengawasan (ar-riqobah) ${ }^{7}$

\footnotetext{
${ }^{6}$ Raymundus, "PERENCANAAN MANAJEMEN STRATEGIS DAN KEPUASAN KERJA TERHADAP KINERJA PEGAWAI (Studi Kasus pada KRL Commuter Line Bogor-Jakarta)", Business Management Journal, Vol.14 (No. 2 ) : 75 - 153. Th. 2018, Jakarta, hal: 141

${ }^{7}$ http://modernis.co/manajemen-strategi-prespektif-islam-dalam-perusahaan/24/04/2020 diaskes pada pukul 23.40 tanggal 12 september 2021.
} 


\section{BAB III PENUTUP}

\section{A. Kesimpulan}

Manajemen strategi adalah perencanaan berskala besar (disebut Perencanaan Strategi) yang berorientasi pada jangkauan masa depan yang jauh (disebut VISI), dan ditetapkan sebagai keputusan manajemen puncak (keputusan yang bersifat mendasar dan prinsipil), agar memungkinkan organisasi berinteraksi secara efektif (disebut MISI), dalam usaha menghasilkan sesuatu (Perencanaan Operasional) yang berkualitas, dengan diarahkan pada optimalisasi pencapaian tujuan (disebut Tujuan Strategik) dan berbagai sasaran (Tujuan Operasional) organisasi."

Setelah membaca beberapa pengertian diatas dapat kami simpulkan manajemen strategi itu penting. Alasan pertama yang paling penting adalah bahwa hal itu dapat membedakan seberapa baik kinerja perusahaan. Organisasi yang menggunakan Manajemen Strategik mempunyai tingkat kinerja yang lebih tinggi dan itu membuatnya cukup penting bagi para manajer. Alasan kedua, hal tersebut penting berhubungan dengan fakta bahwa manaer di semua jenis dan ukuran organisasi terus menghadapi situasi yang berubah. Mereka menghadapi ketidakpastian dengan menggunakan proes manajemen strategik untuk mmeriksa faktorfaktor yang relevan dan memeutuskan tindakan apa yang kan diambil. Alasan terakhir, manajemen merupakan hal yang penting karena organisasi bersifat kompleks dan beragam. Setiap bagian harus bekerja untuk mencapai tujuan organisasi. 


\section{DAFTAR PUSTAKA}

B. Elnath Aldi, "UPAYA GENERALISASI KONSEP MANAJEMEN STRATEGIK", JURNAL ILMU EKONOMI \& SOSIAL, VOL.VI, NO. 2, OKTOBER 2015, Universitas Katolik Indonesia Atma Jaya, hal.66-67.

Onny Juwono, "ANALISIS MANAJEMEN STRATEGIK PERUSAHAAN WARALABA (FRANCHISE) (STUDI KASUS DI RESTORAN CEPAT SAJI McDONALD'S) PERIODE OKTOBER - DESEMBER 2011", Jurnal Ekonomika dan Manajemen, hal. 9-11.

Rangkuti, Fredy, "Strategi promosi yang kreatif dan Analisis Kasus Intergrated Marketing Communication, Jakarta: PT. Gramedia Pustaka Utama, 2009, hal. 6.

Raymundus, "PERENCANAAN MANAJEMEN STRATEGIS DAN KEPUASAN KERJA TERHADAP KINERJA PEGAWAI (Studi Kasus pada KRL Commuter Line Bogor-Jakarta)", Business Management Journal, Vol.14 (No. 2 ) : 75 - 153. Th. 2018, Jakarta, hal: 141

Sujadi, "KONSEP MANAJEMEN STRATEGIK SEBAGAI PARADIGMA BARU DI LINGKUNGAN ORGANISASI PENDIDIKAN", JURNAL STIE SEMARANG, VOL 3, NO 3, Edisi Oktober 2011, STIE Semarang, hal. 2-3.

http://asaraagama.com/manajemen/manajemen-strategis diakses pada pukul 23.0 tanggal 12 September 2021

http://modernis.co/manajemen-strategi-prespektif-islam-dalam-perusahaan/24/04/2020 diaskes pada pukul 23.40 tanggal 12 september 2021. 